\title{
Interactions between Pied crows Corvus albus and breeding White-backed vultures Gyps africanus
}

Article

Accepted Version

Johnson, T. F. and Murn, C. (2019) Interactions between Pied crows Corvus albus and breeding White-backed vultures Gyps africanus. Ethology Ecology \& Evolution, 31 (3). pp. 240-248. ISSN 0394-9370 doi:

https://doi.org/10.1080/03949370.2018.1561523 Available at https://centaur.reading.ac.uk/82252/

It is advisable to refer to the publisher's version if you intend to cite from the work. See Guidance on citing.

To link to this article DOI: http://dx.doi.org/10.1080/03949370.2018.1561523

Publisher: Taylor and Francis

All outputs in CentAUR are protected by Intellectual Property Rights law, including copyright law. Copyright and IPR is retained by the creators or other copyright holders. Terms and conditions for use of this material are defined in the End User Agreement.

www.reading.ac.uk/centaur 
Central Archive at the University of Reading

Reading's research outputs online 


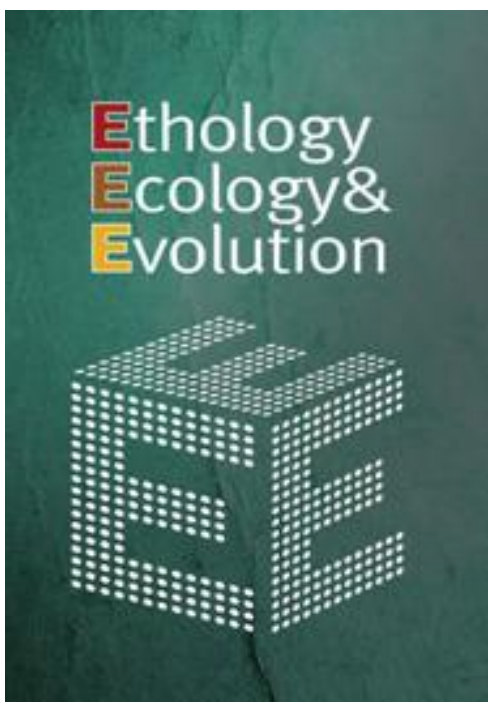

\section{Interactions between Pied crows Corvus albus and breeding White-backed vultures Gyps africanus}

\begin{tabular}{|c|c|}
\hline Journal: & Ethology Ecology \& Evolution \\
\hline Manuscript ID & TEEE-2018-0051.R3 \\
\hline Manuscript Type: & Short Communications \\
\hline $\begin{array}{r}\text { Date Submitted by the } \\
\text { Author: }\end{array}$ & $\mathrm{n} / \mathrm{a}$ \\
\hline Complete List of Authors: & $\begin{array}{l}\text { Johnson, Thomas; University of Leeds, Faculty of Biological Sciences } \\
\text { Murn, Campbell; Hawk Conservancy Trust, ; University of Reading, } \\
\text { School of Biological Sciences }\end{array}$ \\
\hline Keywords: & Nest, Disturbance, Egg, Predation \\
\hline
\end{tabular}

\section{SCHOLARONE \\ Manuscripts}




\section{Short communication}

3 Interactions between Pied crows Corvus albus and breeding White10 11

\section{4 backed vultures Gyps africanus}

5 Thomas F. JOHNSON ${ }^{1}$ and CAMPBell MURN (iD 2,3,*

61 Faculty of Biological Sciences, School of Biology, University of Leeds, Leeds, England

$7 \quad{ }^{2}$ Hawk Conservancy Trust, Andover, Hampshire, SP11 8DY, England

$8{ }^{3}$ School of Biological Sciences, University of Reading, Berkshire, RG6 6AS, England

$9 \quad{ }^{*}$ Corresponding author: Campbell Murn, Hawk Conservancy Trust, Andover, Hampshire, SP11 8DY, England (E-mail: campbell@hawkconservancy.org). 


\section{Abstract}

18 African White-backed vultures Gyps africanus are Critically Endangered, mainly due to mortality 


\section{INTRODUCTION}

35 Nest failure in birds can be caused by a variety of factors such as infertility (Jamieson \& Ryan 2000), egg-shell thinning (Castilla et al. 2010), predation (Feare et al. 2017), and modification to nesting habitat (Evans 2003). For vultures and other long-lived raptors, disturbance by humans (Bamford et al. 2009) can be a important cause of breeding failure (Borello \& Borello 2002), Determining the actual cause of low breeding productivity in birds can thus be challenging and, in some cases, important for identifying threats to endangered birds (Hemmings et al. 2012).

White-backed vultures Gyps africanus are Critically Endangered (Birdlife International 2016), mainly due to rapid population declines caused by poisoning mortality, where several hundred vulture can the wildlife trade or electrocution on power lines (Ogada et al. 2016). They also exhibit a variable breeding success across their range, from $50-60 \%$ in South Africa to over $80 \%$ in East Africa (Mundy et al. 1992). Whilst the major causes of mortality in White-backed vultures have been identified, such as poisoning and harvesting for belief-based use (Ogada et al. 2016), it is still unclear why breeding productivity varies between regions and years.

Near Kimberley in central South Africa, there is a population of approximately 170 breeding pairs of White-backed vultures (Murn et al. 2017) that has been at least partially monitored since the 1960s (Forrester 1967). Within the Kimberley area, some local ecologists and land owners suspect that White-backed vulture nest failure and subsequent low breeding productivity is caused by egg and chick predation, with Pied crows Corvus albus, and to a lesser extent, Vervet monkeys Chlorocebus pygerythrus, considered the most likely nest predators. Given that Pied crows are well-known as nest predators (Carlson \& Hartman 2001; Sensory Ecology 2013a, 2013b), it is possible that they predate on vulture eggs and chicks, and negative interactions between corvids and vultures have been recorded elsewhere (Bertran \& Margalida 2005). However, at about $10 \%$ of their weight (Hockey et al. 2005), Pied crows are considerably smaller than White-backed vultures and it seems unlikely that Pied crows could force a White-backed vulture from its nest. Regardless, as the Pied crow population in central and southwestern South Africa has grown and expanded over recent 
61 decades (Cunningham et al. 2016), speculation has arisen that crows might be negatively affecting 62 White-backed vulture breeding productivity. Despite these concerns, there are no data or published 63 accounts of interactions between nesting White-backed vultures and Pied crows. Speculation 64 cannot inform conservation management decisions and there is a recognised need for research to understand the existence and/or degree of threat posed by Pied crows to other bird species in South Africa (BirdLife South Africa 2012). 


\section{METHODS}

88 The study was conducted between May-August 2015 at Dronfield Nature Reserve (28.64S, 24.80E) 89 and Mokala National Park (29.17S, 24.32E), both located near Kimberley, South Africa. These two 00 2 92 16 protected areas are approximately $60 \mathrm{~km}$ apart and contain the two largest breeding colonies of White-backed vultures in the Kimberley area, with an estimated 75 and 55 breeding pairs at Dronfield and Mokala respectively (Murn et al. 2002, 2017). The habitat at both sites is part of the savanna biome, with a Kimberley thornveld vegetation type (Mucina \& Rutherford 2006). The vultures nest in the two most common large tree species in the region: Camel thorn Vachellia erioloba and Umbrella thorn Vachellia tortilis.

\section{Detecting nest predators}

To determine if egg or chick predation was responsible for White-backed vulture nest failure, 10 camera traps (Prostalk@ PC4000 5.0 megapixel, with a $60^{\circ}$ passive infrared sensor) were deployed at active vulture nests. Cameras were programmed to take photos at $30 \mathrm{~min}$ intervals, and also whenever there was movement on the nest via an infrared trigger. The cameras were installed in the nest tree, but not directly in the nest, and were angled to capture visitors to the nest and the surrounding canopy at a distance of $1.5-3 \mathrm{~m}$ from the nest edge.

To identify nest predators we also made 14 dummy eggs, similar in size and shape to White-backed vulture eggs and deployed these in two settings. Six dummy eggs were placed in unused (inactive) White-backed vulture nests (mean area $=113 \mathrm{~cm}^{2}$, mean depth $=50 \mathrm{~cm}$ ). The other eight dummy eggs were placed in hand-made nests (mean area $=72 \mathrm{~cm}^{2}$, mean depth $=26 \mathrm{~cm}$ ) in trees nearby to active vulture nests. Eggs were constructed of polyurethane foam (commonly used in taxidermy) and surrounded by a layer of plasticine (painted white) to record bite and scratch marks. Eggs were attached to the nesting tree with string to prevent any animals from completely removing the egg from the nest; grass lining was used to hide the string.

Any marks on the eggs were photographed and measured to catalogue the impressions made by potential predators. Two nests with dummy eggs were monitored with camera traps to record 
113 visitors and also calibrate the marks left on the eggs. Unclear impressions or those not captured by 114 camera were identified using museum specimens (teeth, beak, claw and fingers) from a variety of 115 known regional nest predators.

10116

12

13117

14

15

17

18119

19

20120

21

22121

23

24

25122

26

27

$28^{123}$

29

30

31

32

$33^{125}$

34

$35^{126}$

36

37127

38

39128

40

41129

42

43130

44

45131

46

47

48132

49

50

51133

52

53

54134

55

56135

57

58136

59

60137

\section{Assessing nest disturbance}

The camera traps on active vulture nests recorded the presence or absence and number of Pied crows from the point the egg was laid until the egg either hatched or was abandoned by the vultures. We defined mobbing or disturbance behaviour as the presence of one or more Pied crows in the nest tree for greater than $1 \mathrm{~min}$.

\section{Analysis}

To determine if mobbing or nest disturbance increased the probability of vultures abandoning their nest, we performed a logistic regression with abandoned vs not-abandoned as the response variable, and Pied crow mobbing nest (present vs absent) as the predictor. Next, we assessed whether the frequency of Pied crow visits changed as the breeding season progressed in both the abandoned and not-abandoned categories. We performed a logistic regression with Pied crow mobbing nest (present vs absent) as the response, with number of days since egg was laid as a predictor, interacting with outcome (abandoned vs not-abandoned). Analyses were conducted using R 3.2.3 (R Core Team 2015).

\section{RESULTS}

\section{Dummy eggs}

Dummy eggs were exposed to potential predation over a combined 456 egg/days. All 14 dummy eggs were predated at least twice; on average 3.6 times (range: 2-6). Of the 47 predation events recorded, 28 were in unused vulture nests and 19 in hand-made nests. Pied crows were the most common nest predator $(79 \%, n=37)$, followed by unidentified large raptors $(6 \%, n=3)$, White- 

$5139 \quad(11 \%, n=5)$.

140 Active nests $0.12, P=0.90)$.

backed Vultures $(2 \%, n=1)$ and Vervet Monkeys $(2 \%, n=1)$. Five marks could not be identified

On the 10 active nests with camera traps, three eggs were predated. Pied crows were responsible for two of these predation events (Fig. 1A); the final predation event, or its timing in relation to the egg being incubated, was not recorded due to camera trap failure. Eggs were only predated after the nest had been abandoned by the vultures for five, nine, and 10 days. On the nest where the egg was predated five days after abandonment, Pied crows visited the nest each day after the vultures left and viewed the egg for 4 days before eating it on the 5th day.

Pied crows were recorded mobbing eight of the 10 nests under observation. Vultures that abandoned their nests experienced significantly more $(Z=6.32, P<0.001)$ mobbing than on nonabandoned nests (Table 1). The frequency of this mobbing did not change throughout the breeding season across all nests $(Z=0.04, P=0.97)$, or between abandoned and non-abandoned nests $(Z=$

Mobbing occupied only a small fraction of the total observation period for each nest (total attendance ranged from $696-1752 \mathrm{hr} /$ nest), and there was high variation in the number of times crows visited nests (Table 1). Often, just one crow would visit the nest, but in some cases, up to nine Pied Crows were observed mobbing one nest at a time (Fig. 1B). Mobbing only occurred during daylight hours (Table 1).

\section{Observations regarding predation and dummy eggs}

Two Vervet monkeys were observed through binoculars chasing a vulture from its nest. The vulture flew to an adjacent tree $\sim 50 \mathrm{~m}$ from the nest, whilst the two monkeys sat in the nest for $\sim 5.5 \mathrm{~min}$ before departing and joining the rest of the troop. Their activity in the nest was unclear as they were facing away from the observer. Once they were gone, the vulture returned to its nest and resumed 
163 incubating. Ten min later the observer climbed the tree to find the egg undamaged, and 20 days 164 later the egg hatched.

White-backed Vultures were observed incubating dummy eggs on three separate occasions at three separate nests (two inactive nests, one hand-made nest). These 'incubation' periods lasted from 18-45 min, with one pair of birds swapping with each other to share incubation duties. Birds were only observed incubating on each dummy egg once.

\section{DISCUSSION}

Our results show that Pied crows predated dummy eggs more than any other species and that two of the abandoned eggs under observation were eaten by Pied crows. Although mobbing by Pied crows appeared to increase the probability vultures would abandon their nest, Pied crows did not eat eggs in abandoned nests at the earliest opportunity. We found little or no evidence for the threat of egg and chick predation by large raptors or primates.

The apparent increase in the probability of nest abandonment by vultures due to Pied crow mobbing highlights that population growth of Pied crows may impact White-backed vulture breeding productivity negatively. This disturbance at the nest was unexpected, as White-backed vultures are considerably larger than Pied crows, and we had hypothesised it would be unlikely that Whitebacked vultures would be intimidated by crows. This is the first evidence to support speculation that Pied crows may affect White-backed vulture breeding productivity. However, given the small sample size, it is important for the results in this study to be expanded - both within the Kimberley area and at other locations where Pied crow densities are different.

Pied crows returning to view the same abandoned egg on 5 consecutive days before opting to eat it may be a type of food caching or it could be that crows actively seek non-viable or abandoned eggs. However this would be unusual as the egg remained unhidden in the same location and could either have been eaten by other nest predators or the vultures could have returned to incubate the egg. We are unaware of reports of Pied crows exhibiting food caching, but it is a common behaviour in other corvid species (Grodzinski \& Clayton 2010). 
We found no evidence that Vervet monkeys predate White-backed vulture eggs at our study sites 190 around Kimberley. With clear bite marks in a dummy egg and a real egg left undamaged, it is 191 possible the monkey only bit the dummy egg out of curiosity, and they are not actually nest

predators of White-backed vultures, unlike other avian species (Patterson et al. 2016).

The interactions of White-backed vultures with dummy eggs, both in terms of clawing at and biting a dummy egg and also 'incubating' dummy eggs are intriguing and warrant further research. Infanticide by birds other than the parents has been recorded in colonial breeding raptor species (Steen et al. 2016), but attempted infanticide seems an unlikely reason for a vulture to bite an apparently abandoned egg. Polygamous breeding, however, has been observed in Bearded vultures Gypaetus barbatus (Bertran \& Margalida 2004) and other raptors (Tingay et al. 2002) and this offers some potential insight into reasons for the 'incubation' of dummy eggs.

With White-backed vulture populations in decline, understanding the causes of nesting failure will potentially inform conservation management options. Our findings need to be compared with similar studies in other regions (e.g. Maphalala \& Monadjem 2017), and on other large raptor species (e.g. Murn \& Holloway 2014), to determine if the threat to breeding White-backed vultures from Pied crows or other nest visitors is high (cf. Thompson et al. 2017). However, if Pied crow mobbing is a cause of White-backed vulture nest abandonment, it is important to understand the implications and severity of this for the demography of vulture populations in the light of continued adult vulture mortality from poisoning, energy infrastructure and a range of other threats.

\section{ACKNOWLEDGEMENTS}

Thanks to Fritz Viljoen who was essential in developing the dummy eggs, Beryl Wilson and the McGregor Museum who provided access to museum specimens, Angus Anthony, Ronelle Visagie, Jarryd Elan-Puttick, Charles Hall, Corné Anderson and Amy Rebecca Cardwell. The manuscript was improved by comments from Lindy Thompson. 
215 Provided by International Vulture Programme partners, in particular Puy du Fou (FR).

PERMISSIONS

\section{AUTHOR CONTRIBUTIONS}

The authors contributed equally to this paper.

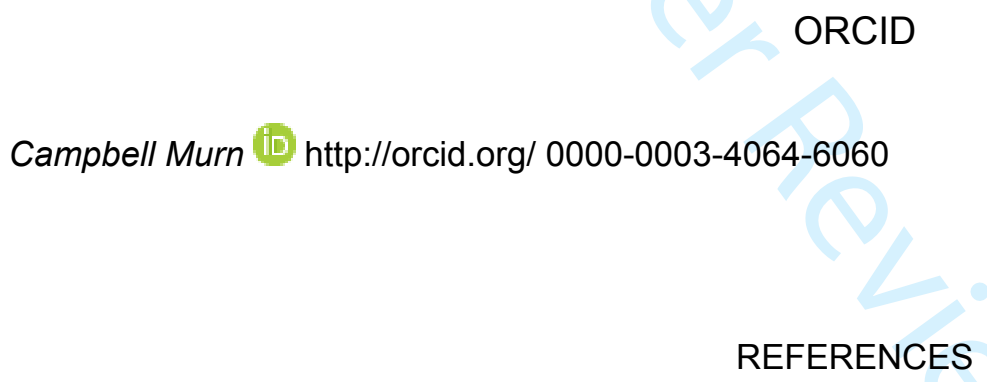

Bamford AJ, Monadjem A, Hardy ICW. 2009. Nesting habitat preference of the African White-backed Vulture Gyps africanus and the effects of anthropogenic disturbance. Ibis. 151:51-62.

Bertran J, Margalida A. 2004. Do females control matings in polyandrous bearded vulture Gypaetus barbatus trios? Ethol Ecol Evol. 16:181-186.

Betran J, Margalida A. 2005. Interactive behaviour between bearded vultures Gypaetus barbatus and common ravens Corvus corax: predation risk and kleptoparasitism. Ardeola. 51:269-274

Birdlife International. 2016. Gyps africanus. IUCN Red List Threatened Species 2015. Available on: http://www.iucnredlist.org/details/22695189/0 [Accessed 18 Jan 2018].

BirdLife South Africa. 2012. Position statement on the potential impact of an increased abundance of Pied Crows Corvus albus on South African biodiversity [WWW Document]. BirdLife. Available on: http://birdlife.org.za/about-us/our-organisation/position-statements [Accessed 18 Jan 2018]. 
Borello WD, Borello RM. 2002. The breeding status and colony dynamics of Cape Vulture Gyps coprotheres in Botswana. Bird Cons Int. 12:79-97.

Carlson A, Hartman G. 2001. Tropical forest fragmentation and nest predation - an experimental study in an Eastern Arc montane forest, Tanzania. Biodivers Conserv. 10:1077-1085.

Castilla AM, Herrel A, Robles H, Malone J, Negro JJ. 2010. The effect of developmental stage on eggshell thickness variation in endangered falcons. Zoology. 113:184-188.

Cunningham SJ, Madden CF, Barnard P, Amar A. 2016. Electric crows: Powerlines, climate change and the emergence of a native invader. Divers Distrib. 22:17-29.

Evans KL. 2003. The potential for interactions between predation and habitat change to cause population declines of farmland birds. Ibis. 146:1-13.

Feare CJ, van der Woude J, Greenwell P, Edwards HA, Taylor JA, Larose CS, Ahlen PA, West J, Chadwick W, Pandey et al. 2017. Eradication of common mynas Acridotheres tristis from Denis Island, Seychelles. Pest Manag Sci. 73:295-304.

Forrester A. 1967. Some observations made on white-backed vultures (Gyps africanus) while nesting. Bokmakierie. 19:6-8.

Grodzinski U, Clayton NS. 2010. Problems faced by food-caching corvids and the evolution of cognitive solutions. Philos Trans R Soc Lond B. 365:977-87.

Hemmings N, West M, Birkhead TR.2012. Causes of hatching failure in endangered birds. Biol Lett. 8:964-7.

Hockey PAR, Dean WRJ,Ryan PG. 2005. Roberts. Birds of Southern Africa, 7th ed. Cape Town : Trustees of the John Voelcker Bird Book Fund.

Jamieson IG, Ryan CJ. 2000. Increased egg infertility associated with translocating inbred takahe (Porphyrio hochstetteri) to island refuges in New Zealand. Biol Conserv. 94:107-114.

Maphalala MI, Monadjem A. 2017. White-backed Vulture Gyps africanus parental care and chick growth rates assessed by camera traps and morphometric measurements. Ostrich. 88:123-129.

Margalida A, Arroyo BE, Bortolotti GR, Bertran J. 2006. Prolonged incubation in raptors: adaptive or 
nonadaptive behaviour? J Rap Res. 40:159-163.

Mucina L, Rutherford MC. 2006. The vegetation of South Africa, Lesotho and Swaziland. Strelitzia. 19.

Mundy P, Butchart D, Ledger J, Piper S. 1992. The vultures of Africa. London (UK): Academic Press.

Murn C, Anderson MD, Anthony A. 2002. Aerial survey of African white-backed vulture colonies around Kimberley, Northern Cape and Free State provinces, South Africa. South African J WildI Res. 32:145152.

Murn C, Botha A. 2017. A clear and present danger: impacts of poisoning on a vulture population and the effect of poison response activities. Oryx. 52:552-558.

Murn C, Botha A, Wilson B. 2017. The changing sizes of Critically Endangered White-backed Vulture breeding colonies around Kimberley, South Africa. African J WildI Res. 47:144-148.

Murn C, Combrink L, Ronaldson GS, Thompson C, Botha A. 2013. Population estimates of three vulture species in Kruger National Park, South Africa. Ostrich 84:1-9.

Murn C, Holloway GJ. 2014. Breeding biology of the White-headed Vulture Trigonoceps occipitalis in Kruger National Park, South Africa. Ostrich 85:125-130

Ogada D, Shaw P, Beyers RL, Buij R, Murn C, Thiollay J-M, Beale CM, Holdo RM, Pomeroy D, Baker N, et al. 2016. Another continental vulture crisis: Africa's vultures collapsing toward extinction. Conserv Lett. 9:89-97

Patterson L, Kalle R, Downs C. 2016. Predation of artifical bird nests in suburban gardens of KwaZulu-Natal, South Africa. Urban Ecosyst. 19:615-630

R Core Team. 2015. R: A language and environment for statistical computing. Vienna (Austria): R Foundation for Statistical Computing.

Sensory Ecology. 2013a. Pied Crow stealing Blacksmith Plover eggs [WWW Document]. Available on: https://www.youtube.com/watch?v=SiOUgJdJHpY [Accessed 18 Jan 2018].

Sensory Ecology. 2013b. Chestnut-banded Plover eggs being eaten by an African Pied Crow [WWW Document]. Available on: https://www.youtube.com/watch?v=zOCGVVgfbq4 [Accessed 18 Jan 2018]. 
2

3290 Steen R, Miliou A, Tsimpidis T, Selås V, Sonerud GA. 2016. Nonparental Infanticide in Colonial Eleonora's 11 13 14295 15 16296 17 18 $19^{297}$ 20 21298 22 23 24 25 26 27 28 29 30 31 32 33 34 35 36 37 38 39 40 41 42 43 44 45 46 47 48 49 50 51 52 53 54 55 56 57 58 59 60 falcons (Falco eleonorae). J Raptor Res. 50:217-220.

Thompson LJ, Davies JP, Gudehus M, Botha AJ, Bildstein KL, Murn C, Downs CT. 2017. Visitors to nests of Hooded vultures Necrosyrtes monachus in northeastern South Africa. Ostrich 88:155-162.

Tingay RE, Culver M, Hallerman EM, Fraser JD, Watson RT. 2002. Subordinate males sire offspring in Madagascar fish-eagle (Haliaeetus vociferoides) polyandorus breeding groups. J Raptor Res. 36:280286. 
301 List of Tables and Figures:

Table 1. 11303 12 $13^{304}$ 14 15305 16 17306 18 19 $20^{307}$ 21 22308 24 25309 26 27310 28 29 $30^{311}$ 31 32 33 34 35

Fig. 1. - (A) A Pied crow eating an abandoned White-backed vulture egg. Egg abandoned 5 days prior to predation. (B) Eight Pied crows mobbing a nesting White-backed vulture. Nest was later abandoned by parent birds and the egg was then predated by Pied crows. 
Table 1.

315 Summary statistics for Pied crow mobbing of nesting White-backed vultures. Values highlighted in grey are $10^{316}$ from nests abandoned by White-backed vultures, white are non-abandoned nests. The eggs in the two abandoned nests listed at the top of the table were both predated by Pied crows after nest abandonment.

\begin{tabular}{|c|c|c|c|c|c|}
\hline $\begin{array}{l}\text { Period nest was } \\
\text { under observation } \\
\text { (days) }\end{array}$ & $\begin{array}{l}\text { Total time crows } \\
\text { present at the nest } \\
\text { (hr) }\end{array}$ & $\begin{array}{l}\text { Time crows present at nest } \\
\text { per day - column } 2 \text { divide } \\
\text { column } 1 \text { (min) }\end{array}$ & $\begin{array}{l}\text { Number of times a } \\
\text { crow visited the } \\
\text { nest }(N)\end{array}$ & $\begin{array}{l}\text { Mean number of } \\
\text { crows } \pm \text { standard } \\
\text { deviation }(\mathrm{N})\end{array}$ & $\begin{array}{l}\text { Mobbing time } \\
\text { frame (hh:mm) }\end{array}$ \\
\hline 60 & 2.00 & 2.00 & 12 & $2.16 \pm 1.93$ & $06: 40-15: 45$ \\
\hline 32 & 0.17 & 0.32 & 2 & $1 \pm 0$ & 09:00-11:20 \\
\hline 28 & 0 & 0 & 0 & - & - \\
\hline 60 & 0.50 & 0.50 & 5 & $1.37 \pm 0.52$ & $07: 20-11: 20$ \\
\hline 60 & 0.08 & 0.08 & 1 & $1 \pm 0$ & 08:10-08:10 \\
\hline 60 & 0 & 0 & 0 & - & - \\
\hline 60 & 0.08 & 0.08 & 1 & $1 \pm 0$ & $08: 45-08: 45$ \\
\hline 55 & 0.17 & 0.18 & 1 & $1 \pm 0$ & 09:25-09:30 \\
\hline 40 & 0.08 & 0.12 & 1 & $1 \pm 0$ & $10: 25-10: 25$ \\
\hline 29 & 0.25 & 0.52 & 3 & $1 \pm 0$ & $08: 40-12: 05$ \\
\hline
\end{tabular}




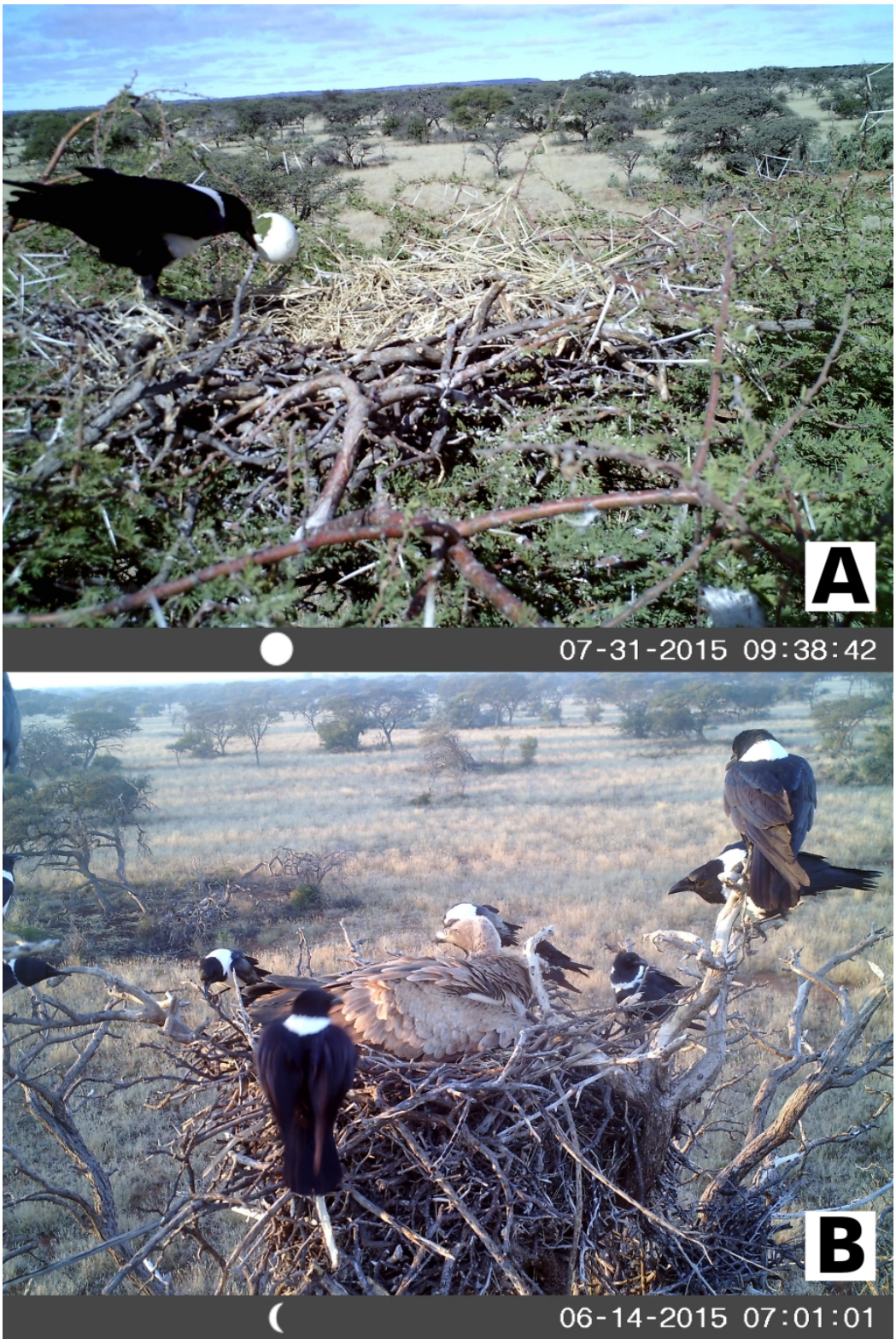

(A) A Pied crow eating an abandoned White-backed vulture egg. Egg abandoned 5 days prior to predation. (B) Eight Pied crows mobbing a nesting White-backed vulture. Nest was later abandoned by parent birds and the egg was then predated by Pied crows.

$903 \times 1354 \mathrm{~mm}(72 \times 72$ DPI $)$ 